\title{
P Wave Signal-Averaged Electrocardiography in Patients with Chronic Obstructive Pulmonary Disease
}

\author{
C.A. BUZEA ${ }^{1,2}$, ANCA RODICA DAN ${ }^{2}$, CATERINA DELCEA ${ }^{2}$, M.I. BALEA ${ }^{2}$, DANIELA GOLOGANU ${ }^{2}$, \\ MIHAELA DOBRANICI ${ }^{1,2}$, RALUCA ALEXANDRA POPESCU ${ }^{1,2}$, G.A. DAN ${ }^{1,2}$ \\ 1“Carol Davila” University of Medicine and Pharmacy, 37 Dionisie Lupu, Bucharest, District 1, 020022 Romania \\ 2“"Colentina” Clinical Hospital,19-21Ştefan cel Mare, Bucharest, District 2, 020125, Romania
}

\begin{abstract}
Introduction. Chronic obstructive pulmonary disease (COPD) is associated with higher incidence of supraventricular arrhythmias. Atrial late potentials (ALP) detected by P-wave signal-averaged electrocardiography (SAECG) could be useful in detecting the patients at risk for supraventricular arrhythmias. Our objective was to assess the role of P-wave SAECG and ALP detection for arrhythmic risk evaluation of the patients with exacerbated COPD.

Methods. We prospectively included 45 patients with exacerbation of COPD and 58 agematched patients with no history of pulmonary disease in a control group. We performed pulmonary function tests, arterial blood gases, echocardiography, 24-hour Holter monitoring and P-wave SAECG. We measured filtered P-wave duration (FPD), the root mean square (RMS) voltages in the last 40, 30 and $20 \mathrm{~ms}$ of the filtered P-wave (RMS 40, RMS 30 and RMS 20), the root mean square voltage of the filtered P-wave potentials (RMS-p), and the integral of the potentials during the filtered P-wave (Integral-p). ALP was defined as FPD $>132 \mathrm{~ms}$ and RMS $20<2.3 \mu \mathrm{V}$.

Results. Isolated atrial premature beats (APB) and supraventricular tachycardias (SVT) were more frequent in the COPD group. There were no significant differences between groups regarding the $\mathrm{P}$ wave SAECG parameters. In the COPD group none of the supraventricular arrhythmias was correlated with ALP or any P-wave SAECG parameters.

Conclusions. The patients with acute exacerbation of COPD but no apparent cardiac disease have a higher incidence of supraventricular arrhythmias. P-wave SAECG analysis and ALP detection have little value in the arrhythmic risk evaluation of these patients.
\end{abstract}

Key words: COPD, chronic obstructive pulmonary disease, supraventricular arrhythmias, atrial late potential, signal-averaged electrocardiography.

\section{INTRODUCTION}

It has long been recognized that chronic obstructive pulmonary disease (COPD) is associated with an increased risk for both supraventricular and ventricular arrhythmias [1] and their occurrence represents a sign of a poor prognosis [2]. Atrial late potentials (ALP) detected by $\mathrm{P}$ wave signal-averaged electrocardiography (SAECG) have been demonstrated to be directly linked to the atrial fibrillation development [3, 4]. ALP are low amplitude, high frequency signals which appear at the end of atrial depolarization, primarily as a consequence of delayed or fragmented conduction. We aim to analyze the role of $\mathrm{P}$ wave SAECG and ALP detection for arrhythmic risk evaluation of the patients with acute exacerbation of COPD.

\section{MATERIAL AND METHODS}

We included 45 patients diagnosed with COPD according to the Global Initiative for Chronic Obstructive Lung Disease (GOLD) criteria
[5], presented to our clinic with acute exacerbation of the disease, and 58 age-matched patients without any history of pulmonary disease in the control group. We excluded patients with history or signs of ischemic heart disease, with history of myocardial revascularization or cardiac surgery, significant valvular disease, known atrial fibrillation or other chronic arrhythmias, heart failure or left ventricular ejection fraction (LVEF) $<50 \%$, known thyroid dysfunction, permanent bundle block, on antiarrhythmic treatments or with permanent implantable devices. All patients signed a written informed consent. The study protocol was approved by our institution's Ethics Committee. The study population was prospectively included between June 2014 and June 2015 from a single hospital center.

\section{PROCEDURES}

\section{Pulmonary function tests}

Pulmonary function testing was performed using a Vitalograph Alpha 6000 spirometer (Vitalograph, Ireland) for all patients with COPD. Forced 
vital capacity (FVC) and forced expiratory volume in the first second (FEV1) were measured in milliliters and expressed as percentages of the predicted values established by the European Community Respiratory Health Survey. Samples for the arterial blood gases were obtained from the radial artery in all patients with COPD while breathing room air. $\mathrm{pH}, \mathrm{pO}_{2}, \mathrm{pCO}_{2}$ and $\mathrm{HCO} 3$ results were recorded. Also, the oxygen saturation by pulseoxymetry was analyzed in all patients.

\section{Echocardiography}

The echocardiographic examination was performed with an iE33 xMATRIX (Philips, The Netherlands) system with 2.5-3.5 MHz transducers. M-mode and 2D-dimensional measurements were done in all standard windows, according to the recommendations of the European Society of Echocardiography. The left ventricular ejection fraction (LVEF) was calculated using Simpson's biplane method and pulmonary artery pressure (PAP) was calculated using the modified Bernoulli equation: $\mathrm{PAP}=4 \times($ tricuspid systolic jet) $2+10 \mathrm{~mm} \mathrm{Hg}$.

\section{Holter Recordings}

Twenty-four hour ambulatory ECG recordings were obtained with a CardioMem ${ }^{\circledR}$ CM 3000 (GE Healthcare, Germany) system. The recordings were downloaded to a CardioDayHolter software (GE Healthcare, Germany). These were reviewed by a cardiology specialist to confirm 18 hours of clear recording, and the beat classifications were manually checked and corrected. The recordings were screened for atrial arrhythmias defined as isolated atrial premature beats (APB), with a predefined category of patients with more than 70 ABP per day $(\mathrm{APB}>70)$, and supraventricular tachycardias (SVT) consisting in atrial tachycardias, atrial flutter or atrial fibrillation.

\section{Signal-averaged electrocardiography}

SAECG was performed in all patients using a MAC 5500HD (GE Healthcare, Germany) system. The $\mathrm{P}$ wave SAECG parameters measured were the filtered P-wave duration (FPD), the root mean square (RMS) voltages in the last 40, 30 and $20 \mathrm{~ms}$ of the filtered P-wave (RMS 40, RMS 30 and RMS 20), the root mean square voltage of the filtered P-wave potentials (RMS-p), and the integral of the potentials during the filtered $\mathrm{P}$-wave
(Integral-p). The values were recorded when a noise level $<1 \mu \mathrm{V}$ was obtained, by averaging $\geq$ 250 beats. ALP was defined as FPD $>132 \mathrm{~ms}$ and RMS20 $<2.3 \mu \mathrm{V}[6]$.

\section{Statistical analysis}

Statistical analysis was performed with NCSS 10 Statistical Software (NCSS, LLC. Kaysville, Utah, USA) and Medcalc 15.2 (MedCalc Software, Ostend, Belgium). The normality was tested with D'Agostino-Pearson and Komolgorov-Smirnov tests. Descriptive statistics values were given as mean \pm standard deviation and percentage ratios. The differences between groups were analyzed using chisquared test or Mann-Whitney test as appropriate. The correlations between non-normally distributed variables were obtained using Spearman's correlation test. The impact of factors on the presence or absence of SVT was analyzed using logistic regression with backward method. The $\mathrm{p}$ values $<$ 0.05 were considered statistically significant.

\section{RESULTS}

The demographic characteristics and clinical examination differences between the COPD patients and the control group are shown in Table 1. As expected, COPD patients have a significantly higher respiratory rate and lower oxygen saturation compared to the control group. Also, the history of smoking and active smoking is more frequent in COPD patients.

Regarding the echocardiographic parameters we did not find any significant differences between the groups, except for a higher systolic pulmonary artery pressure and a statistically non-significant higher diameter of the right ventricle in the COPD patients as shown in Table 2.

The incidence of both APB and SVT was higher in the COPD group. Compared to the control group, among these patients the APB $>70$ category was more frequent (Table 3 ).

The $\mathrm{P}$ wave SAECG analysis demonstrated no significant differences in any parameters between COPD and control patients, with the exception of RMS 20 which was higher in COPD patients with marginally statistical significance. Moreover, the presence of ALP was the same in both study groups. The results regarding SAECG analysis are given in Table 4. 
Table 1

General characteristics

\begin{tabular}{|c|c|c|c|}
\hline & $\begin{array}{c}\text { COPD } \\
(n=45)\end{array}$ & $\begin{array}{l}\text { Control } \\
(\mathrm{n}=58)\end{array}$ & p value \\
\hline \multicolumn{4}{|c|}{ Demographics and co-morbidities } \\
\hline Age, y & $64.6 \pm 9.2$ & $63.4 \pm 9.2$ & 0.8 \\
\hline Male gender, $\mathrm{n}$ & $32(71.1 \%)$ & $31(53.4 \%)$ & 0.07 \\
\hline BMI, $\mathrm{kg} / \mathrm{m}^{2}$ & $30.8 \pm 8.6$ & $28.4 \pm 4.8$ & 0.6 \\
\hline History of smoking, $\mathrm{n}$ & $38(84.4 \%)$ & $7(12.1 \%)$ & $<0.001$ \\
\hline Active smoking, $\mathrm{n}$ & $27(60 \%)$ & $4(6.9 \%)$ & $<0.001$ \\
\hline Arterial hypertension, $\mathrm{n}$ & $25(55.5 \%)$ & $35(60.3 \%)$ & 0.7 \\
\hline Diabetes mellitus, $\mathrm{n}$ & $11(24.4)$ & $7(12.1 \%)$ & 0.1 \\
\hline \multicolumn{4}{|l|}{ Clinical examination } \\
\hline $\mathrm{SBP}, \mathrm{mmHg}$ & $132.7 \pm 22.9$ & $131.4 \pm 14.1$ & 0.7 \\
\hline $\mathrm{DBP}, \mathrm{mmHg}$ & $78.5 \pm 15.9$ & $78.9 \pm 10$ & 0.8 \\
\hline Heart rate, bpm & $84.2 \pm 16.3$ & $76.5 \pm 16.9$ & 0.1 \\
\hline Respiratory rate, rpm & $25.1 \pm 7$ & $18.3 \pm 3.5$ & $<0.001$ \\
\hline Oxygen saturation, $\%$ & $88.6 \pm 6.7$ & $97.64 \pm 2.6$ & $<0.001$ \\
\hline
\end{tabular}

Table 2

Echocardiographic measurements

\begin{tabular}{lccc}
\hline & COPD $(\mathbf{n}=\mathbf{4 5})$ & Control $(\mathbf{n}=\mathbf{5 8})$ & p value \\
\hline LA, mm & $36.8 \pm 7.1$ & $34.0 \pm 5.1$ & 0.1 \\
LVESD, mm & $34.5 \pm 5.9$ & $33.1 \pm 6.4$ & 0.4 \\
LVEDD, mm & $47.8 \pm 5.2$ & $47.4 \pm 5.7$ & 0.8 \\
IVS, mm & $12.1 \pm 1.9$ & $11.5 \pm 2.1$ & 0.2 \\
LVPW, mm & $11.4 \pm 1.6$ & $10.6 \pm 1.8$ & 0.06 \\
LVEF, \% & $55.7 \pm 7.5$ & $57.2 \pm 3.6$ & 0.2 \\
$\mathrm{RA}, \mathrm{mm}$ & $34.2 \pm 5.3$ & $32.5 \pm 5.3$ & 0.1 \\
$\mathrm{RV}, \mathrm{mm}$ & $28.2 \pm 5.3$ & $26.8 \pm 2.8$ & 0.08 \\
sPAP, mmHg & $30.1 \pm 12.8$ & $19.8 \pm 10.7$ & 0.005 \\
\hline LA - left atrium, LVESD - left ventricular end-systolic diameter, LVEDD - left ventricular \\
end-diastolic diameter, IVS - interventricular septum, LVPW - left ventricular posterior \\
wall, LVEF - left ventricular ejection fraction, RA-right atrium, RV-right ventricle, sPAP- \\
systolic pulmonary artery pressure \\
\hline
\end{tabular}

Table 3

Incidence of supraventricular arrhythmias

\begin{tabular}{lccc}
\hline & COPD $(\mathbf{n}=\mathbf{4 5})$ & Control $(\mathbf{n}=\mathbf{5 8})$ & p value \\
\hline APB & $901.9 \pm 1535.4$ & $416.4 \pm 876.3$ & 0.04 \\
APB $>70$ & $29(64.4 \%)$ & $27(46.5 \%)$ & 0.07 \\
SVT & $27(60 \%)$ & $16(27.6 \%)$ & $<0.001$ \\
\hline
\end{tabular}

$A P B$ - atrial premature beats, $A P B>70$ - more than 70 atrial premature beats $/ 24 h$, SVTsupraventricular tachycardias

Table 4

P-wave SAECG analysis and ALP incidence

\begin{tabular}{|c|c|c|c|}
\hline & $\begin{array}{c}\text { COPD } \\
(n=45)\end{array}$ & $\begin{array}{l}\text { Control } \\
(n=58)\end{array}$ & p value \\
\hline FPD, ms & $126.2 \pm 43.8$ & $125.2 \pm 38.4$ & 0.9 \\
\hline RMS $40, \mu \mathrm{V}$ & $6.7 \pm 3.7$ & $5.5 \pm 2.2$ & 0.1 \\
\hline RMS $30, \mu \mathrm{V}$ & $5.9 \pm 3.7$ & $4.6 \pm 2.1$ & 0.1 \\
\hline RMS $20, \mu \mathrm{V}$ & $4.8 \pm 2.9$ & $3.6 \pm 1.9$ & 0.04 \\
\hline RMS-p, $\mu \mathrm{V}$ & $7.7 \pm 2.9$ & $7.3 \pm 2.3$ & 0.4 \\
\hline Integral-p, $\mu \mathrm{V}^{*} \mathrm{~s}$ & $755.8 \pm 257.9$ & $723.3 \pm 296.9$ & 0.3 \\
\hline ALP, $n$ & $8(17.8 \%)$ & $11(18.9 \%)$ & 0.8 \\
\hline \multicolumn{4}{|c|}{$\begin{array}{l}\text { FPD - Filtered } P \text { wave duration, } R M S 40, R M S 30, R M S 20-\text { root mean square (RMS } \\
\text { voltage of the terminal } 40,30,20 \mathrm{~ms} \text { of the filtered } P \text { wave, } R M S-p-R M S \text { voltage of th } \\
\text { entire filtered } P \text { wave, Integral- } p-\text { integral of the voltages in the entire } P \text { wave }\end{array}$} \\
\hline
\end{tabular}


In the COPD group there was a statistically significant correlation between FEV1 and FPD $\left(\mathrm{r}_{\mathrm{s}}=0.49, \mathrm{p}=0.001\right)$, RMS $40\left(\mathrm{r}_{\mathrm{s}}=-0.46, \mathrm{p}=\right.$ 0.002), RMS $30\left(\mathrm{r}_{\mathrm{s}}=-0.48, \mathrm{p}=0.001\right)$, RMS 20 $\left(r_{s}=-.38, p=0.01\right)$, RMS-p $\left(r_{s}=-.38, p=0.01\right)$, but no correlations were found between other respiratory tests and $\mathrm{P}$ wave SAECG parameters. Also, the $\mathrm{pCO}_{2}$ was correlated with RMS $40\left(\mathrm{r}_{\mathrm{s}}=\right.$ $0.54, \mathrm{p}=0.003)$, RMS $30\left(\mathrm{r}_{\mathrm{s}}=0.52, \mathrm{p}=0.004\right)$ and RMS $20\left(\mathrm{r}_{\mathrm{s}}=0.46, \mathrm{p}=0.01\right)$, but not with other SAECG parameters.

Regarding the echocardiographic measurements, in the COPD group we observed a significant but rather weak correlation between left ventricular end-systolic (LVESD) and end-diastolic (LVEDD) diameters and FPD $\left(\mathrm{r}_{\mathrm{s}}=0.35, \mathrm{p}=0.02\right.$ for LVEDV and $r_{s}=0.34, p=0.03$ for LVESV). No other relationships between $P$ wave SAECG and echocardiographic parameters were found.
However, in the COPD group there were no significant differences between patients with ALP and those without ALP regarding the $\mathrm{APB}>70$ category or the incidence of SVT (see Figure 1). In the logistic regression $\left(r^{2}=0.61, \mathrm{p}=0.001\right)$ the presence of SVT in these patients is correlated only with $\mathrm{pO}_{2}$ and FEV1, but not with any $\mathrm{P}$-wave SAECG parameters. Also, we did not find a relationship between echocardiographic measurements and $\mathrm{APB}>70$ or SVT.

An analysis on subgroups of COPD classes showed no differences in terms of P wave SAECG parameters, including the incidence of ALP (Table 5). The supraventricular arrhythmias seem to appear more frequently in patients with stage IV COPD compared to those with stages I to III, but without reaching statistical significance: $\mathrm{APB}>70(73.7 \%$ vs $57.7 \%, \mathrm{p}=0.17)$ and SVT $(63.1 \%$ vs $53.8 \%$, $\mathrm{p}=0.1)$.

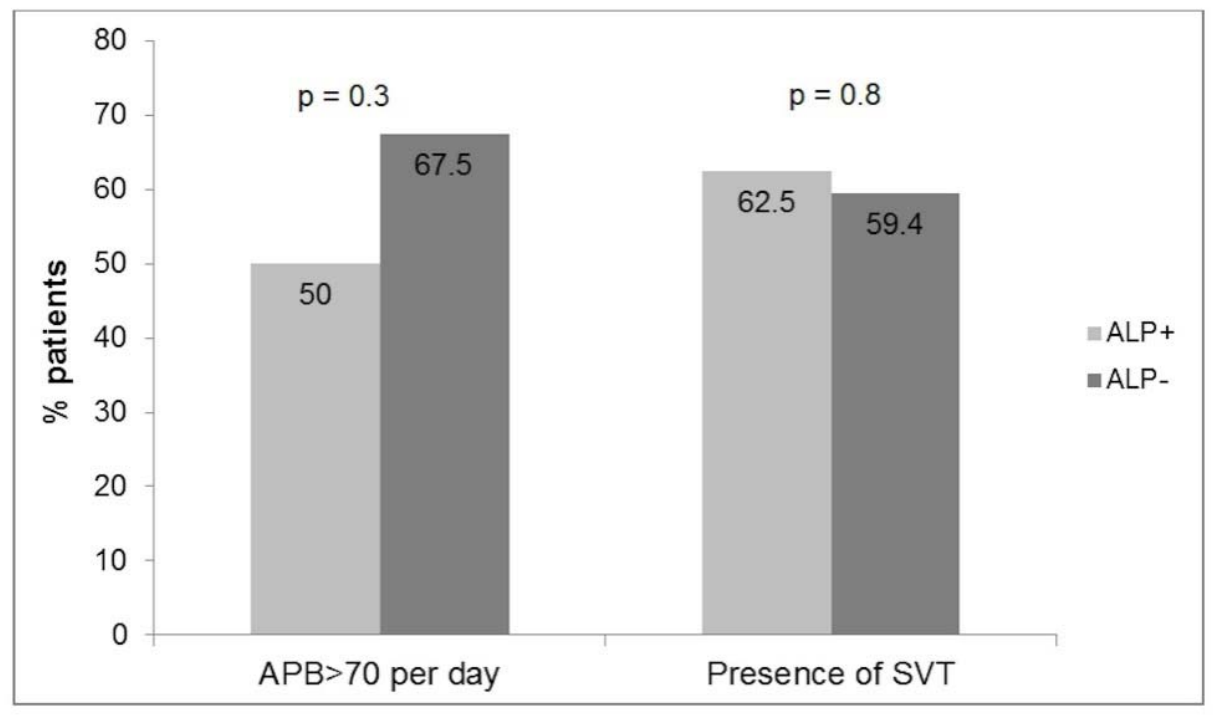

Figure 1. ALP and incidence of supraventricular arrhythmias in COPD patients.

Table 5

$\mathrm{P}$-wave SAECG parameters in relation to COPD classes

\begin{tabular}{|l|l|l|l|}
\hline & \multicolumn{1}{|c|}{$\begin{array}{c}\text { Class II-III } \\
(\mathbf{n}=\mathbf{2 6})\end{array}$} & \multicolumn{1}{|c|}{$\begin{array}{c}\text { Class IV } \\
(\mathbf{n}=\mathbf{1 9})\end{array}$} & \multicolumn{1}{|c|}{ p-value } \\
\hline FPD, $\mathrm{ms}$ & $135.1 \pm 53.1$ & $115.1 \pm 24.8$ & 0.2 \\
\hline $\mathrm{RMS} 40, \mu \mathrm{V}$ & $6.4 \pm 3.5$ & $7.4 \pm 3.8$ & 0.4 \\
\hline $\mathrm{RMS} 30, \mu \mathrm{V}$ & $5.4 \pm 2.6$ & $6.6 \pm 4.3$ & 0.5 \\
\hline $\mathrm{RMS} 20, \mu \mathrm{V}$ & $4.5 \pm 2.3$ & $5.4 \pm 3.5$ & 0.5 \\
\hline $\mathrm{RMSp}, \mu \mathrm{V}$ & $7.9 \pm 3.2$ & $8.1 \pm 2.2$ & 0.2 \\
\hline Integral-p, $\mu \mathrm{V}^{*} \mathrm{~s}$ & $804.3 \pm 249$ & $733.9 \pm 212.4$ & 0.5 \\
\hline $\mathrm{ALP}$ positive, \% & 23.1 & 10.5 & 0.2 \\
\hline $\begin{array}{l}\text { FPD }- \text { Filtered P wave duration, RMS 40, RMS 30, RMS 20 - root mean square (RMS) } \\
\text { voltage of the terminal 40, 30, 20 ms of the filtered P wave, RMS- } p-R M S \text { voltage of the } \\
\text { entire filtered P wave, Integral- } p-\text { integral of the voltages in the entire P wave }\end{array}$ \\
\hline
\end{tabular}




\section{DISCUSSION}

The patients with COPD are at higher risk for developing supraventricular arrhythmias and their occurrence is associated with poor prognosis [2, 7-9]. Several studies showed that $\mathrm{P}$ wave SAECG analysis and the identification of ALP could be used in exposing those patients at risk for atrial fibrillation $[3,4,10-13]$. We aimed to evaluate the role of ALP and $\mathrm{P}$ wave SAECG parameters as tools for risk stratification for developing supraventricular arrhythmias in COPD patients. In our study the patients with COPD had a higher incidence of supraventricular arrhythmias, defined as isolated atrial premature beats or supraventricular tachycardias consisting in atrial tachycardias, atrial flutter or atrial fibrillation, compared to a control group. Also, the predefined category of more than 70 APB per day is more frequent in the COPD patients. Regarding the $\mathrm{P}$ wave SAECG analysis we did not find significant differences of the values of any parameter, including the presence of ALP, between the COPD and control group. Moreover, in the analysis of the COPD group there were no correlations between ALP and isolated APB or SVT. The predictive role of $\mathrm{P}$ wave SAECG was studied in different clinical situations. Steinberg et al. [4] and Caravelli et al. [10] demonstrated the potential role of $P$ wave SAECG in the prediction of atrial fibrillation after cardiac surgery or coronary artery by-pass grafting. In a prospective study, Yamada et al. [6] showed the association between presence of ALP and atrial fibrillation in patients with heart failure. Recently, ALP detection was found useful in patients with ischemic stroke of unknown origin [12]. To date, we did not find any study regarding $\mathrm{P}$ wave SAECG in the setting of COPD. Moreover, in comparison with the above mentioned trials we excluded the patients with significant cardiac diseases like ischemic heart disease or heart failure. This and the fact that our patients have mostly normal echocardiographic parameters could be an explanation for the lack of significant modification of the $P$ wave SAECG parameters. In our study neither the presence of ALP nor any of the P wave SAECG parameters correlated with the supraventricular arrhythmias in the COPD patients. The incidence of SVT was more related with the severity of respiratory function reflected in FEV1 and $\mathrm{pO}_{2}$, which was also demonstrated in previous studies $[14,15]$. This finding lowers the usefulness of $\mathrm{P}$ wave SAECG analysis in the prediction of supraventricular arrhythmias during the exacerbations of COPD, especially when there are no significant morphological or functional alterations of the heart.

A limitation of our study is the relatively small population size, recruited from a single center. Also, as our findings are based on a crosssectional analysis we cannot rule out the role of ALP or any P wave SAECG parameter as predictor for developing arrhythmias in the medium or long term. For this further prospective research is needed.

\section{CONCLUSIONS}

The patients with COPD and no apparent cardiac disease have a higher incidence of supraventricular arrhythmias during acute exacerbations, seemingly in direct relationship with the severity of the altered respiratory function. The $\mathrm{P}$ wave SAECG analysis and the presence of ALP add little value in the stratification of patients with COPD at risk of supraventricular arrhythmias. Acknowledgements. This paper is supported by the Sectoral
Operational Programme Human Resources Development (SOP
HRD), financed from the European Social Fund and by the
Romanian Government under the contract number POSDRU/
159/1.5/S/137390.

We thank Marian Miricioiu and Carmen Adam who were responsible for technical aspects of Holter monitoring and SAECG.

Conflicts of interest: none.

Introducere. Boala cronică pulmonară obstructivă (BPOC) asociază o incidență crescută a tahiaritmiilor supraventriculare. Potențialele atriale tardive (ALP) detectate prin metoda "P-wave signal-averaged electrocardiography" (SAECG) ar putea fi utilă pentru identificarea pacienților aflați la risc pentru tahiaritmii supraventriculare. Obiectivul studiului a fost de a determina rolul metodei P-wave SAECG pentru evaluarea riscului aritmic la pacienții cu exacerbare a $B P O C$.

Metode. Au fost incluşi prospectiv 45 de pacienți cu exacerbare a BPOC şi 58 de pacienți fără antecedente de boală pulmonară. Au fost analizate funcția 
pulmonară, valorile gazelor sanguine, ecocardiografie, monitorizare Holter pe parcursul a 24 de ore şi $P$-wave SAECG. Au fost măsurate duratele undei P filtrate (FPD), voltajul root mean în ultimele 40, 30 şi 20 de ms ale undei P filtrate (RMS 40, RMS 30 şi RMS 20), voltajul potențialelor root mean square ale undei P 9RMS-p) şi integrala potențialelor din timpul undei $P$ filtrate (Integral-p). ALP au fost definite ca FPD $>132 \mathrm{~ms}$ şi RMS $20<2.3 \mu \mathrm{V}$.

Rezultate. Bătăile premature isolate atriale $(A P B)$ şi tahiaritmiile supraventriculare (SVT) au fost mai frecvente în grupul cu BPOC. Nu a fost observată nicio diferență privind parametrii $P$ wave SAECG între cele două grupuri. In grupul cu BPOC niciuna dintre tahiaritmiile supraventriculare $n u s$-a corelat $\mathrm{cu}$ ALP sau cu parametrii P-wave SAECG.

Concluzii. Pacienții cu exacerbare a BPOC dar fără boală cardiacă aparentă au o incidență mai mare a aritmiilor supraventriculare. Analiza P-wave SAECG şi identificarea ALP au o valoare redusă pentru evaluarea riscului aritmic al acestor pacienți.

Correspondence to: Cătălin Adrian Buzea

"Colentina" Clinical Hospital, 19-21 Ștefan cel Mare, Bucharest, District 2, 020125, Romania

Phone: +40 745771745

E-mail: adrian_c_buzea@yahoo.com

\section{REFERENCES}

1. WOOD-BAKER R, COCHRANE B, NAUGHTON MT. Cardiovascular mortality and morbidity in chronic obstructive pulmonary disease: The impact of bronchodilator treatment. Intern. Med. J. 2010; 40:94-101.

2. FUSO L, INCALZI RA, PISTELLI R, MUZZOLON R, VALENTE S, PAGLIARI G,et al. Predicting mortality of patients hospitalized for acutely exacerbated chronic obstructive pulmonary disease. Am. J. Med. 1995; 98:272-7.

3. FUKUNAMI M, YAMADA T, OHMORI M. Detection of patients at risk for paroxysmal atrial fibrillation during sinus rhythm by $P$ wave-triggered signal-averaged electrocardiogram. Circulation 1991; 83(1):162-9.

4. STEINBERG JS, ZELENKOFSKE S, WONG SC, GELERNT M, SCIACCA R, MENCHAVEZ E. Value of the P-wave signalaveraged ECG for predicting atrial fibrillation after cardiac surgery. Circulation. 1993; 88:2618-22.

5. RABE KF, HURD S, ANZUETO A, BARNES PJ, BUIST SA, CALVERLEY P, et al. Global strategy for the diagnosis, management, and prevention of chronic obstructive pulmonary disease: GOLD executive summary. Am. J. Respir. Crit. Care Med. 2007; 176:532-55.

6. YAMADA T, FUKUNAMI M, SHIMONAGATA T, KUMAGAI K, OGITA H, ASANO Y, et al. Prediction of paroxysmal atrial fibrillation in patients with congestive heart failure: a prospective study. J. Am. Coll. Cardiol. 2000; 35:405-13.

7. SHIH HT, WEBB CR, CONWAY WA, PETERSON E, TILLEY B, GOLDSTEIN S.Frequency and significance of cardiac arrhythmias in chronic obstructive lung disease. Chest. 1988; 94:44-8.

8. BHATT SP, DRANSFIELD MT. Chronic obstructive pulmonary disease and cardiovascular disease. Transl. Res. 2013; 162:237-51.

9. KONECNY T, PARK JY, SOMERS KR, KONECNY D, ORBAN M, SOUCEK F, et al. Relation of chronic obstructive pulmonary disease to atrial and ventricular arrhythmias. Am. J. Cardiol. 2014; 114:272-7.

10. CARAVELLI P, CARLO M, MUSUMECI G, TARTARINI G, GHERARDUCCI G, BORTOLOTTI U, et al. P-wave signalaveraged electrocardiogram predicts atrial fibrillation after coronary artery bypass grafting. Ann. Noninvasive Electrocardiol. 2002; 7:198-203.

11. DARBAR D, JAHANGIR A, HAMMILL SC, GERSH BJ. P wave signal-averaged electrocardiography to identify risk for atrial fibrillation. Pacing Clin. Electrophysiol. 2002; 25:1447-53.

12. YODOGAWA K, SEINO Y, OHARA T, HAYASHI M, MIYAUCHI Y, KATOH T, et al. Prediction of atrial fibrillation after ischemic stroke using $P$-wave signal averaged electrocardiography. J. Cardiol. Japanese College of Cardiology; 2013; 61:49-52.

13. MILITARU C, DONOIU I, IONESCU D-D. P wave signal-averaged ECG in normal population and in patients with converted atrial fibrillation. Ann. Noninvasive Electrocardiol. 2011; 16:351-6.

14. BUCH P, FRIBERG J, SCHARLING H, LANGE P, PRESCOTT E. Reduced lung function and risk of atrial fibrillation in the Copenhagen City Heart Study. Eur. Respir. J. 2003; 21:1012-6.

15. TERZANO C, ROMANI S, CONTI V, PAONE G, ORIOLO F, VITARELLI A. Atrial fibrillation in the acute, hypercapnic exacerbations of COPD. Eur. Rev. Med. Pharmacol. Sci. 2014; 18:2908-17.

Received August 31, 2015 